\title{
Deep-water longline fishing has reduced impact on Vulnerable Marine Ecosystems
}

SUBJECT AREAS:

BIODIVERSITY

CONSERVATION

Received

12 February 2014

Accepted

31 March 2014

Published

29 April 2014

Correspondence and requests for materials should be addressed to

T.M. (telmo@uac.pt)

\author{
Christopher K. Pham, Hugo Diogo, Gui Menezes, Filipe Porteiro, Andreia Braga-Henriques, \\ Frederic Vandeperre \& Telmo Morato
}

Departamento de Oceanografia e Pescas, IMAR and LARSyS Associated Laboratory, Universidade dos Açores, $9901-862$ Horta, Portugal.

Bottom trawl fishing threatens deep-sea ecosystems, modifying the seafloor morphology and its physical properties, with dramatic consequences on benthic communities. Therefore, the future of deep-sea fishing relies on alternative techniques that maintain the health of deep-sea ecosystems and tolerate appropriate human uses of the marine environment. In this study, we demonstrate that deep-sea bottom longline fishing has little impact on vulnerable marine ecosystems, reducing bycatch of cold-water corals and limiting additional damage to benthic communities. We found that slow-growing vulnerable species are still common in areas subject to more than 20 years of longlining activity and estimate that one deep-sea bottom trawl will have a similar impact to 296-1,719 longlines, depending on the morphological complexity of the impacted species. Given the pronounced differences in the magnitude of disturbances coupled with its selectivity and low fuel consumption, we suggest that regulated deep-sea longlining can be an alternative to deep-sea bottom trawling.

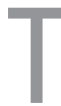
he expansion of fishing activities into deeper waters ${ }^{1}$ is unquestionably one of the principal threats to the world's ocean health ${ }^{2}$. Most deep-sea fisheries are unsustainable not only for target species but also for nontarget fauna and their habitats ${ }^{3}$. Unless some radical changes in governance and management are being made ${ }^{4}$, damages to deep-sea ecosystems will soon be irreversible. The United Nations have recognized this issue and has urged governments and Regional Fishery Management Organizations to assess the impact of deep-sea fisheries on Vulnerable Marine Ecosystems (VMEs), particularly on cold-water coral ecosystems ${ }^{5}$. To reach this goal, impact assessments of different types of deep-sea fishing gear and of specific fishery are urgently needed ${ }^{6}$.

Cold-water corals are of significant ecological ${ }^{7}$ and economical value ${ }^{8}$, providing habitat for a wide variety of organisms $s^{9,10}$, many that are of commercial interest ${ }^{9,11}$. They are found in all oceans, in a wide variety of settings including continental shelves, fjords, canyons, seamounts, mounds or island slopes ${ }^{12}$ and are considered as biodiversity hotspots, comparable to the diversity found in tropical coral reefs ${ }^{13}$. In contrast to tropical reefs, the cold temperatures and inconstant food supply in the deep-sea implies that most of cold-water corals have high longevity and reduced growth rates ${ }^{14-16}$, long reproductive cycles and low rates of recruitment ${ }^{17}$. Such life history characteristics imply that cold-water ecosystems have a reduced capacity to recover from disturbance events, such as deep-sea bottom fishing ${ }^{18}$.

Deep-sea bottom trawling is the most destructive form of deep-sea fishing ${ }^{19}$ and an issue of global concern (Fig. 1), since it removes most of these habitat-building organisms from the sea floor ${ }^{20}$. Furthermore, trawling modifies the seafloor morphology and its physical properties ${ }^{21}$, with dramatic consequences on benthic communities ${ }^{20,22}$. Not surprisingly, increasing pressure is being made to ban the use of deep-sea bottom trawls in European waters ${ }^{19}$. Therefore, alternative fishing techniques that maintain the health of deep-sea ecosystems and tolerate appropriated human uses of the marine environment for the benefit of current and future generations are required. Bottom longline is a passive fishing gear considered to have low impact on the benthic environment ${ }^{23}$ but quantitative information is still scarce. Although bycatch of cold-water corals and sponges have been reported for some bottom longline fisheries ${ }^{24-28}$ no studies have effectively assessed the overall level of impact of bottom longline and compared to that of other gear types. Such comparison would help determine the future of deepwater fisheries and contribute to their sustainability. Here, we assessed the impact of deep-sea longline on benthic communities, using data collected aboard commercial fishing vessels, experimental fishing surveys and underwater footage, and compared with the known impact of bottom trawling. 


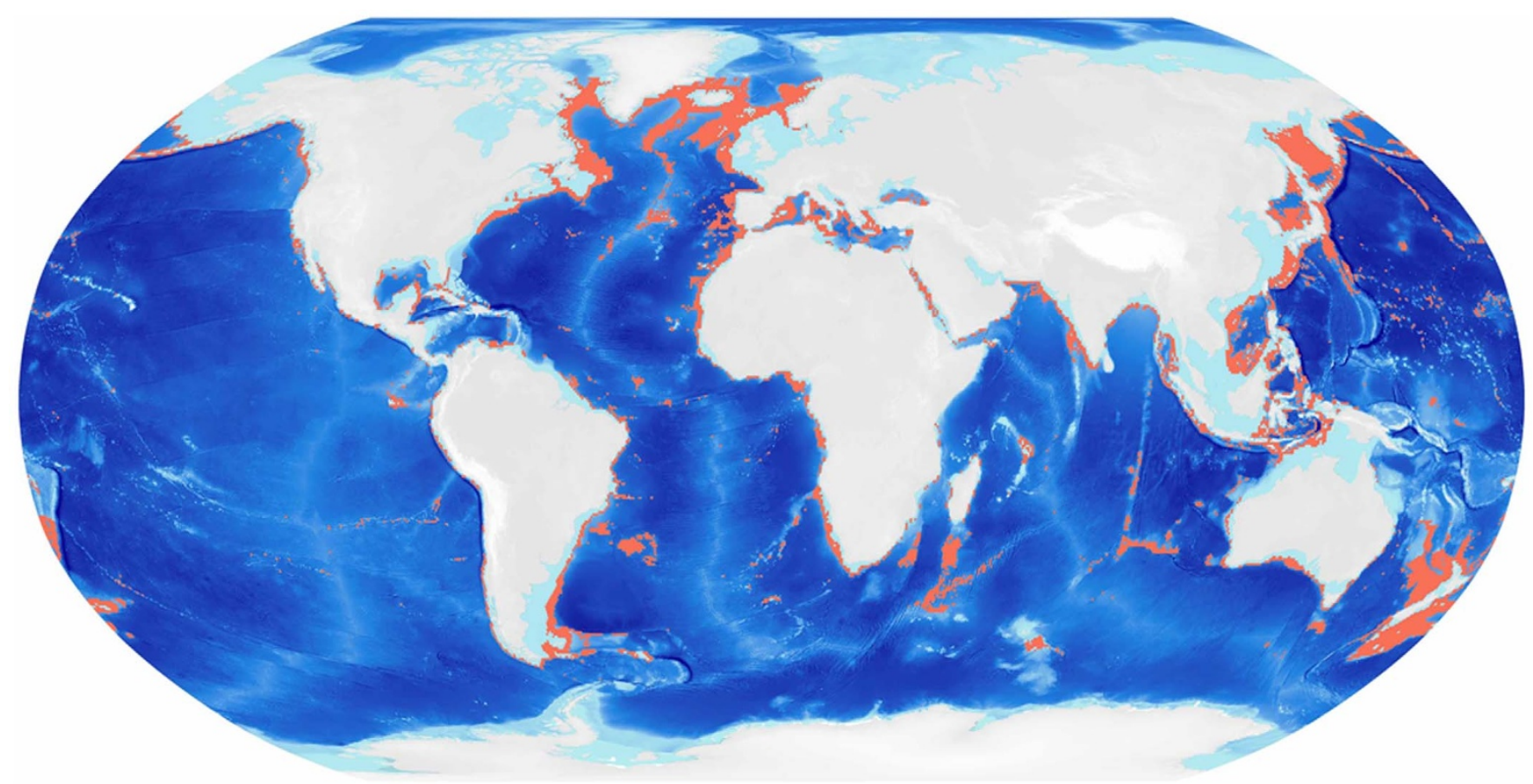

Figure 1 Global map of vulnerable marine ecosystems impacted by deep-sea bottom trawling. Areas in red ilustrate the global extent of deep-sea $(>200 \mathrm{~m})$ bottom trawling mapped from databases developed for global fisheries ${ }^{60}$ on areas of predicted deep-sea vulnerable marine ecosystems mapped from published global habitat suitability models and binary predicted presence maps ${ }^{58,59}$. Map created using a Geographic Information System (ESRI ARCGIS 10.1).

\section{Results}

Bycatch was registered in $44.7 \%$ of the longline sets, removing a wide range of epibenthic organisms (see supplementary Table S1 online). However, the average standardized number of organisms was very small $\left(0.411,000\right.$ hooks $^{-1}$, CI 0.07$)$. When considering solely coldwater corals, average bycatch levels were 0.32 cold-water corals 1,000 hooks ${ }^{-1}$ (CI 0.06). Bycatch was observed throughout the study area in both slopes and offshore seamounts (Fig. 2 and Supplementary Fig. S1 online). Generalized Additive Models suggest that cumulative fishing effort in a particular area did not have a significant effect on bycatch levels of cold-water corals (see supplementary Table S2 online). Although cumulative fishing effort showed an effect in the model fit as evaluated by the Akaike Information Criterion (AIC), it was not a significant covariate (ANOVA; $p=0.06$ ). Therefore, the bycatch rate on a particular fishing ground was not linked to the level of exploitation by the deep-sea bottom fleet in that particular area. Even in the most exploited areas, similar quantities (Kruskal-Wallis; $\mathrm{p}=0.66)$ of epibenthic organisms were caught compared to areas with the lowest fishing effort (Fig. 2) and vulnerable species such as black corals (Antipatharia) were still common bycatch organisms (see Supplementary Fig. S1 online). However, we found that longline mostly (91\% of the bycatch) impact large organisms with a complex morphology (see Supplementary Table S3 and Fig. S2 online).

To provide insights on the level of longline damage not accounted as bycatch, we assessed the physical conditions of benthic communities on a case study fishing ground. From the colonies observed close to lost fishing lines, $63 \%$ were found intact while $15 \%$ were found with minor damage. About $20 \%$ of the colonies were found to have major structural damage but potential for survival. Overall, only $3 \%$ of the cold-water corals were found in a critical status with no survival potential (see Supplementary Table S4 online). Our video survey also showed that the occurrence and severity of impacts were different for two species of contrasting morphologies (see Supplementary Table S4 online). For low complexity single branched corals, bent colonies were the most frequently encountered type of impact whilst for high complexity branched corals, major structural damages were common.

Additionally, we estimated longline removal rates for two species of cold-water corals by comparing bycatch levels with their in situ densities obtained from video footages. Although both species were found in similar densities ( $\mathrm{p}>0.05$ ), removal rate were significantly higher $(\mathrm{p}<0.01)$ for the high complexity branched corals (average; $0.058 \%$ (range $0.038-0.077$ ) compared to the low complexity single branched corals $(0.011 \%$ (range $0.007-0.015)$. Assuming that such removal rates are not density dependent, a total of 4,000 and 23,000 successive longline deployments would be necessary to remove $90 \%$ of the initial density of branched and unbranched cold-water corals, respectively (Fig. 3). Average removal rate of epibenthic organisms per trawl reported in the literature (15.8\%, 4.3 CI; see Supplementary Table S5 online) suggests that only 13 trawls would be required to remove $90 \%$ of the epibenthic organisms present on the seafloor (Fig. 3).

\section{Discussion}

Our analyses suggest that bottom longline has a reduced impact on benthic communities with low bycatch and in situ damages. However, longline will mostly impact organisms with a complex morphology having therefore an unbalanced impact in the ecosystem and eventual long-term shifts in community structure if not effectively managed. Our analyses also suggested that cumulative fishing effort in a particular area did not have a significant effect on bycatch. Species distribution models revealed equal habitat suitability for cold-water corals in both lightly and heavily fished areas (Tempera, unpublished data). Therefore, we expected sites experiencing the most intense longlining activities to have lower bycatch levels compared to locations where fishing is less severe, similarly to what is reported for trawled grounds ${ }^{20}$. However, on one of the most popular fishing ground, where about 50 longline are set each year per $\mathrm{km}^{2}$, bycatch rates were similar to the ones found in sites that have been subject to a less intense fishing effort over the past 20 years. 

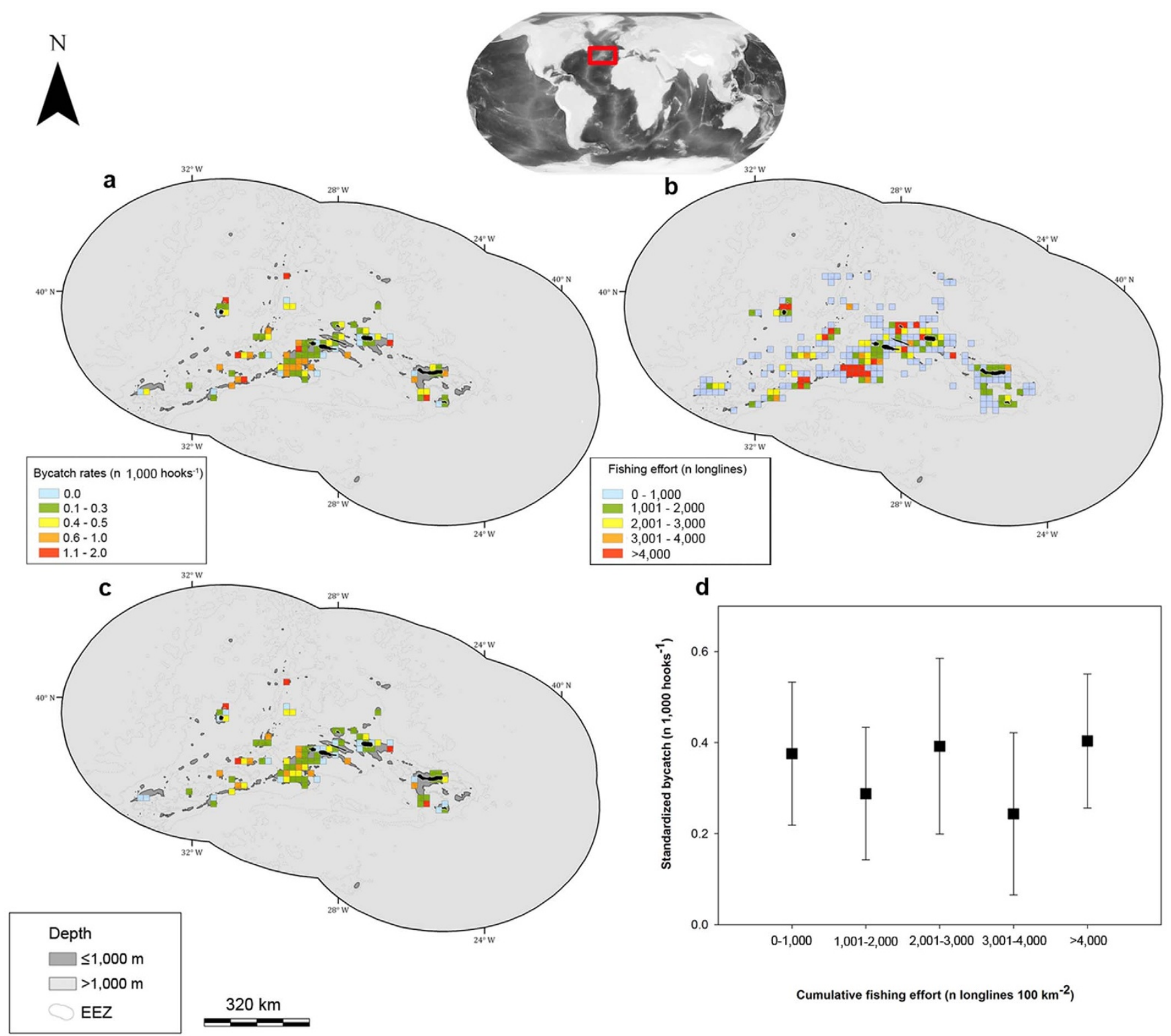

d

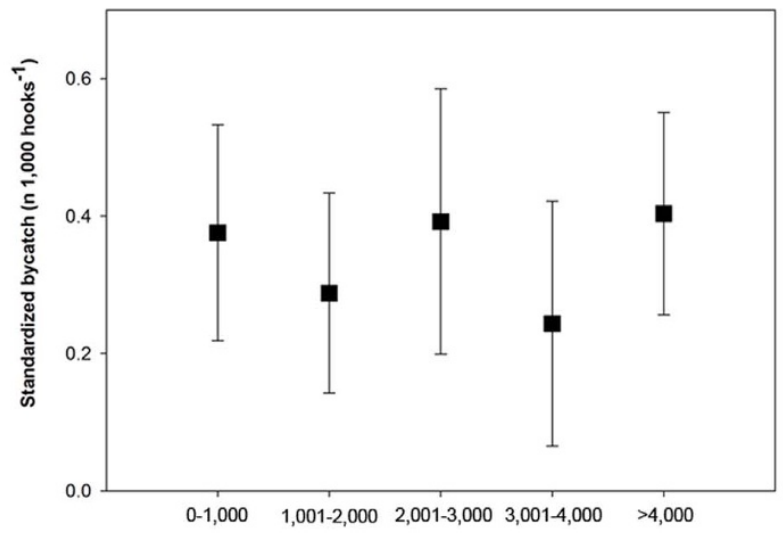

Cumulative fishing effort ( $\mathrm{n}$ longlines $100 \mathrm{~km}^{-2}$ )

Figure 2 Spatial distribution of fishing effort and bycatch of epibenthic organisms in deep-sea bottom longline sets estimated from commercial activities and research cruises in the Azores. Bycatch rates were standardized with General Additive Models. Lighter grey area represents water depths in the Exclusive Economic Zone of the Azores exceeding 1,000 m. (a), all epibenthic organisms, (b), cold-water corals. (c) Fishing effort aggregated over 1998-2012 for the Azores deep-sea longline fleet. (d) Relationship between average bycatch rates of epibenthic organisms and cumulative fishing effort from 1998-2012. Squares represent mean while error bars represent the 95\% confidence intervals. Maps created using a Geographic Information System (ESRI ARCGIS 10.1).

Furthermore, vulnerable species were still common in such highly exploited areas. This implies that epibenthic organisms are still widespread in areas subject to more than 20 years of intense longlining activity and that management measures should ensure limit additional damages. Higher vulnerability to longline fishing of large taxa with complex morphologies is of particular concern because these are generally long-lived species with very slow growth rates (e.g. Leiopathes sp. ${ }^{16}$ ). Removal of such vulnerable organisms may eventually threaten their population since growth and recruitment is outbalanced by the amount removed and population recovery is highly unlikely. As a result, long-term effects of unregulated longlining could result in the complete removal of the most vulnerable forms and leaving those more resilient, but could also result in an increase of some opportunistic fauna that will respond positively to such disturbance, a scenario already documented in trawled habitats ${ }^{29}$.
When comparing our results on the impact of deep-sea longline with the overall impact of bottom trawls on epibenthic invertebrates in other parts of the world, the differences are striking. As opposed to trawled areas, where large epibenthic organisms are generally absent from the most fished locations ${ }^{20,30-32}$, our data suggest that the effects of intense deep-sea longlining were not yet significantly detectable A single deep-sea bottom trawl will have a similar impact on cold-water corals than 296-1,719 longlines; depending on the morphological complexity of the species.

These estimates, however, do not account for organisms that are damaged but not retained in the trawl or longline. Before-AfterControl-Impact experiments on the effect of bottom trawling ${ }^{33}$ showed that the amount of benthic organisms captured is only a small fraction of those that are damaged. Hence, the total mortality rates for trawling are bound to be much higher than those usually 


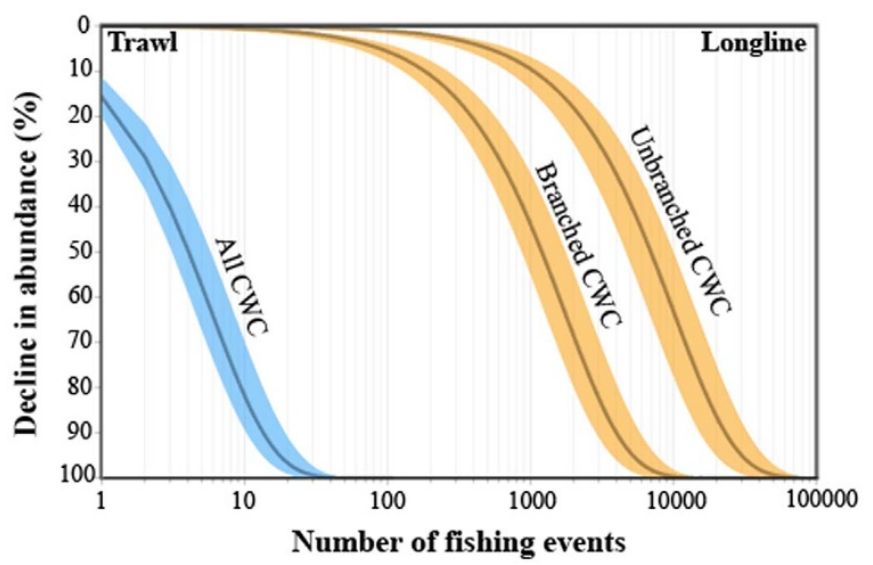

Figure 3 The cumulative impact of deep-sea bottom trawl and longline on cold-water corals. Longline removals rates were estimated in this study and are presented for two species of contrasting morphologies (branched or unbranched). Bottom trawls removal rates were obtained from the literature (see Supplementary Table S5 online). Shaded area represents represent $95 \%$ confidene intervals; $x$ axis is in a $\log _{10}$ scale.

reported in the literature. In contrast to trawled areas, where large epibenthic organisms are completely absent, regardless of their morphology ${ }^{20}$, in the case of longline, our analysis suggested that, most of the cold-water corals were in good conditions and only a small portion was dislocated.

With such pronounced differences in the magnitude of disturbance between trawls and longlines, it is tempting to explore the implications of using deep-sea longlining as an alternative to deepsea trawling. Our analyses suggest that bottom longline fishing has reduced bycatch and in situ damages. Additionally, longline is known to be more size and species selective when compared to bottom trawling and for having reduced bycatch of mobile animals ${ }^{34}$. As a result, bycatch diversity is generally lower for longlines ${ }^{35}$, and the discards rates towards total catch are much lower than for bottom trawling ${ }^{36,37}$. Conversely, bottom longline are recognised to be particularly hazardous for seabird ${ }^{38}$ and deep-sea shark ${ }^{25,35,39,40}$ populations. Contrary to the general perception that turtle bycatch is significant for bottom longline fisheries ${ }^{41}$, it has not been reported for deep-water longline operations. Although, trawls and longlines catch different deep-sea shark species and size frequencies in different locations ${ }^{39,40}$, their bycatch levels are in same order of magnitude (see Supplementary Table S6 online). However, in many locations bycatch of deep-sea sharks in trawls is lower than for longlines but post catch survival is likely to be higher in longlining ${ }^{42}$. Nevertheless, many solutions have been developed to overcome the bycatch of seabirds ${ }^{38}$ and deep-sea sharks ${ }^{40}$.

Another central question arises when considering the potential of deep-sea bottom longline for substituting deep-sea trawling; can longlining catch the same species targeted by trawlers and be equally efficient? For some deep-sea species such as the orange roughy, longlines are inefficient ${ }^{35}$. However, it has been demonstrated that for some fisheries (e.g. cod and haddock in Norway) longline and trawls are equally efficient in catching the target species ${ }^{43}$. Therefore, deepsea longline may offer an economically and practically viable alternative at least for certain fish species and regions around the world (Fig. 1). In addition, longliners have lower energy consumption per tonne of fish catch when compared to deep-sea bottom trawlers ${ }^{44}$. A longliner uses between $0.1-0.3$ tonnes of fuel per tonne of fish ${ }^{34,45}$ whilst the fuel consumption of a high-seas trawler is $0.4-1.3$ tonnes of fuel per tonne of fish ${ }^{44,46}$. Given the low adverse impacts on vulnerable marine ecosystems coupled with its selectivity and low fuel consumption, our work suggests that regulated bottom longline can help achieving sustainability of deep-sea fisheries.

\section{Methods}

Study area and effort data. Deep-sea fisheries in the Azores use longline gears ${ }^{37}$ at depths where cold-water corals are common ${ }^{47}$, creating a unique opportunity to assess the impact of longlining on VMEs. The Azores is a Portuguese archipelago with a maritime territory spreading nearly a million square kilometres where deep-sea trawling is prohibited. To assess the cumulative effect of longline fishing on the seabed, we examined the level of bycatch in areas with different levels of historical exploitation. We obtained data on the spatial distribution of deep-sea fishing effort from interviews made to fishermen between 1998 and 2012, as part of the program of Fisheries Data Collection Programs. The interviews were conducted during landing operations where each fisher was asked to provide the location of their most recent fishing trip on a pre-defined spatial grid with $10 \times 10 \mathrm{~km}$ cells and the total number of hooks set. The number of longline set was then estimated by dividing the number of hooks by 3600 (average number of hooks per longline set). Each cell was then assigned to a category of fishing effort $(0-1000 ; 1001-2000,2001-3000,3001-4000$ and $>4000$ longlines). The number of cells per fishing effort category and the number of longline sets performed to obtain data on bycatch level per effort category can be found in the supplementary material (see Supplementary Table. S7 online).

Bycatch of deep-sea epibenthic organisms. Two observers on-board fishing vessels collected data on the bycatch of epibenthic organisms in 346 longline sets and 43 sets of a hybrid type of longline, done between 2010 and 2011. We included additional bycatch data from 107 longline sets done as part of a deep-sea fish monitoring program ${ }^{48}$. Bycatch organisms were collected, and preserved for identification and morphological classification. For the purpose of this study, cold-water corals included both orders Anthozoa and Hydrozoa. The morphological classification of the epibenthic organisms was adapted from previous assessments ${ }^{26}$. We used three size classes (small: 0-10 cm; medium: 10-60 cm; large: $<60 \mathrm{~cm}$ ) and two categories of complexity (low for organism with simple structures with no ramifications and high for organisms with a 3-dimensional structure with ramifications).

We standardized bycatch data to adjust for differences in bycatch rates between vessels using General Additive Models (GAM) with a negative binomial distribution and a log-link function ( $\mathrm{R}$ package $\mathrm{mgcv}$ ). The response variable was defined as numbers of bycatch organisms ${ }^{26}$ per set with number of hooks as an offset variable. In addition to covariates related to vessel characteristics (vessel id, vessel length, number of crew members), other variables were considered in the model (observer, month, year, type of longline gear, and site category (seamounts or island shelves), depth, fish catch, cumulative fishing effort, and geographical location (latitude and longitude of the mid-point of the longline set). Data exploration revealed some collinearity between vessel id, number of crew members, vessel length and observer. Therefore, only vessel id was considered. Month and year were omitted from model selection procedures due to irregular temporal coverage.

The model selection followed 7 distinct backward steps based on the Akaike information criterion (AIC) and significance of covariates. The final model was Bycatch $\sim \beta+$ Vessel + site category $+s($ depth $)+s($ longitude, latitude $)+$ off set(hooks) $+\varepsilon$, where $\beta$ is an overall intercept, $s$ is an isotropic smoothing function (thin-plate regression spline), and $\varepsilon$ is an error term (see Supplementary Fig. S3 online). Total deviance explained by the model was $38.5 \%$ with an associated dispersion of 1.01. Graphical representation of the residuals suggested no violation of the assumptions (see Supplementary Fig. S.4. online), including no spatial autocorrelation (see Supplementary Fig. S.5 online).

In situ video analysis. To provide insights on the level of in situ damages caused by longline fishing, we assessed the physical conditions of the two dominant cold-water coral species (Viminella flagellum and Dentomuricea aff. meteor) on a case study fishing ground (Condor seamount ${ }^{49}$. Although recently closed to fishing for research purposes, the seamount has been used by local fisherman for decades, using handlines and bottom longline mostly down to $600 \mathrm{~m}$ depth ${ }^{50}$. We performed 48 Remotely Operated Vehicles (ROVs) transects on the summit and northern slope of the seamounts at depths between 166 and 1,092 m. In the laboratory, video analysis consisted in identifying all lost longline segment covered in the video transects. We quantified impact levels of corals close to lost fishing gear to ensure that the observed damages could be attributed to longlining rather than caused by natural disturbance events. The number of cold-water corals in the field of view with a lost longline was recorded and allocated to one of the following physical condition categories: intact, bent, minor damage, major structural damage, displaced or dead (see Supplementary Table S4 online). In addition, we estimated cold-water coral densities throughout the seamount.

Removal rates of deep-sea epibenthic invertebrates. Removal rate was estimated by comparing in situ density (as described above) with bycatch levels of 14 longline sets done at the exact same area. The spatial footprint or swept area of each longline set was estimated using methodologies proposed by Welsford and Kilpatrick ${ }^{51}$. Removal rates were then calculated as the ratio between the number of cold-water corals caught per unit of impacted area and the density of cold-water corals in the area estimated by ROV.

Since the only trawling survey done in the Azores ${ }^{52}$ fail to collect data on the bycatch of epibenthic organisms, we compiled removal rates values reported in the literature around the globe (see Supplementary Table S5 online) to compare with the removal rates estimated for longline. Studies reporting the removal rates of similar epibenthic organisms by bottom trawl varied between 4 and $90 \%$ (see Supplementary Table S5 online). The wide range of removal rates reported in the literature reflects 
differences between the groups of fauna for which the impacts were investigated. Some studies focused on the most vulnerable fauna such as large vulnerable sessile epibenthic species resulting in higher removal rates ${ }^{53,54}$, whilst other studies include all benthic organisms $s^{55,56}$ or just infauna ${ }^{57}$. Studies reporting bottom trawl removal rates for epibenthic organisms used for comparison with the bottom longline estimates looked at similar groups of organisms (see Supplementary Table S5 online).

Global identification of VMEs impacted by deep-sea bottom trawl. Areas of predicted deep-sea vulnerable marine ecosystems were identified from published global habitat suitability models and binary predicted presence maps for seven suborders of Octocorallia ${ }^{58}$ and for five species of framework-forming scleractinian corals $^{59}$. Global map of deep-sea $(>200 \mathrm{~m})$ bottom trawling catch were obtained from Watson ${ }^{60}$ based on databases developed for mapping global fisheries ${ }^{61,62}$. Areas of predicted deep-sea vulnerable marine ecosystems being potentially impacted by bottom trawling were identified by superimposing these global maps.

1. Watson, R. A. \& Morato, T. Fishing down the deep: Accounting for within-species changes in depth of fishing. Fish Res. 140, 63-65, doi:10.1016/j.fishres.2012.12.004 (2013).

2. Glover, A. G. \& Smith, C. R. The deep-sea floor ecosystem: current status and prospects of anthropogenic change by the year 2025. Environ. Conserv. 30, 219-241, doi:10.1017/s0376892903000225 (2003).

3. Norse, E. A. et al. Sustainability of deep-sea fisheries. Marine Policy 36, 307-320, doi:10.1016/j.marpol.2011.06.008 (2012).

4. Guitérrez, N. L., Hilborn, R. \& Defeo, O. Leadership, social capital and incentives promote successful fisheries. Nature 470, 386-389, doi:10.1038/nature09689 (2011)

5. FAO. Report of the Technical Consultation on International Guidelines for the Management of Deep-sea Fisheries in the High Seas, Rome. 4-8 February and 2529 August 2008. FAO Fisheries and Aquaculture Report, 881-886 (2009).

6. ICES. Report of the ICESINAFO Joint Working Group on Deep-water Ecology (WGDEC), 11-15 March 2013, Floedevigen, Norway. ICES CM 2013/ACOM:28. 95 pp. (2013).

7. Roberts, J. M., Wheeler, A. J. \& Freiwald, A. Reefs of the deep: The biology and geology of cold-water coral ecosystems. Science 312, 543-547, doi:10.1126/ science.1119861 (2006)

8. Foley, N. S., van Rensburg, T. M. \& Armstrong, C. W. The ecological and economic value of cold-water coral ecosystems. Ocean Coast. Manage. 53, 313-326, doi:10.1016/j.ocecoaman.2010.04.009 (2010).

9. Costello, M. J. et al. [Role of cold-water Lophelia pertusa coral reefs as fish habitat in the NE Atlantic] Cold-Water Corals and Ecosystems [Freiwald, A. \& Roberts, J. M. (ed.)] [771-805] (Springer-Verlag Berlin, 2005).

10. D'Onghia, G. et al. Effects of deep-water coral banks on the abundance and size structure of the megafauna in the Mediterranean Sea. Deep-Sea Res. Part II-Top. Stud. Oceanogr. 57, 397-411, doi:10.1016/j.dsr2.2009.08.022 (2010).

11. Baillon, S., Hamel, J. F., Wareham, V. E. \& Mercier, A. Deep cold-water corals as nurseries for fish larvae. Front. Ecol. Environ. 10, 351-356, doi:10.1890/120022 (2012).

12. Roberts, J. M., Wheeler, A., Freiwald, A. \& Cairns, S. Cold-Water Corals: The Biology and Geology of Deep-Sea Coral Habitats. (Cambridge University Press, UK., 2009).

13. Watling, L., France, S. C., Pante, E. \& Simpson, A. Biology of deep-water octocorals. Adv. Mar. Biol. 60, 41-123, doi:10.1016/b978-0-12-385529-9.00002-0 (2011).

14. Williams, B., Risk, M. J., Ross, S. W. \& Sulak, K. J. Stable isotope data from deepwater antipatharians: 400 -year records from the southeastern coast of the United States of America. Bull. Mar. Sci. 81, 437-447 (2007).

15. Roark, E. B., Guilderson, T. P., Dunbar, R. B., Fallon, S. J. \& Mucciarone, D. A Extreme longevity in proteinaceous deep-sea corals. Proc. Natl. Acad. Sci. USA. 106, 5204-5208, doi:10.1073/pnas.0810875106 (2009).

16. Carreiro-Silva, M. et al. Variability in growth rates of long-lived black coral Leiopathes sp. from the Azores. Mar. Ecol. Prog. Ser. 473, 189-199, doi:10.3354/ meps10052 (2013).

17. Lacharité, M. \& Metaxas, A. Early life history of deep-water gorgonian corals may limit their abundance. PLoS ONE 8, e65394, doi:10.1371/journal.pone.0065394 (2013).

18. Williams, A. et al. Seamount megabenthic assemblages fail to recover from trawling impacts. Mar. Ecol-Evol. Persp. 31, 183-199, doi:10.1111/j.14390485.2010.00385.x (2010).

19. Watling, L. Deep-sea trawling must be banned. Nature 501, 7-7, doi:10.1038/ nature501007a (2013).

20. Hall-Spencer, J., Allain, V. \& Fossa, J. H. Trawling damage to Northeast Atlantic ancient coral reefs. Proc. R. Soc. Lond. B Biol. Sci. 269, 507-511, doi:10.1098/ rspb.2001.1910 (2002).

21. Puig, P. et al. Ploughing the deep sea floor. Nature 489, 286-+, doi:10.1038/ nature11410 (2012).

22. Watling, L. \& Norse, E. A. Disturbance of the seabed by mobile fishing gear: A comparison to forest clearcutting. Conserv. Biol. 12, 1180-1197, doi:10.1046/ j.1523-1739 (1998).
23. Auster, P. J. et al. Definition and detection of vulnerable marine ecosystems on the high seas: problems with the "move-on" rule. ICES J. Mar. Sci. 68, 254-264, doi:10.1093/icesjms/fsq074 (2011)

24. Parker, S. J. \& Bowden, D. A. Identifying taxonomic groups vulnerable to bottom longline fishing gear in the Ross Sea region. CCAMLR Sci. 17, 105-127 (2010).

25. Muñoz, P. D. et al. Effects of deep-sea bottom longlining on the Hatton Bank fish communities and benthic ecosystem, north-east Atlantic. J. Mar. Biol. Assoc. U. K. 91, 939-952, doi:10.1017/s0025315410001773 (2011).

26. Sampaio, I. et al. Cold-water corals landed by bottom longline fisheries in the Azores (north-eastern Atlantic). J. Mar. Biol. Assoc. U. K. 92, 1547-1555, doi:10.1017/s0025315412000045 (2012).

27. Taylor, M. L., Yesson, C., Agnew, D. J., Mitchell, R. E. \& Rogers, A. D. Using fisheries by-catch data to predict octocoral habitat suitability around South Georgia. J. Biogeogr. 40, 1688-1701, doi:10.1111/jbi.12122 (2013).

28. Mytilineou, C. et al. New cold-water coral occurrences in the Eastern Ionian Sea: Results from experimental long line fishing. Deep-Sea Res. Part II-Top. Stud. Oceanogr. 99, 146-157, doi:10.1016/j.dsr2.2013.07.007 (2014).

29. Jennings, S. \& Kaiser, M. J. The effects of fishing on marine ecosystems. Adv. Mar. Biol. 34, 201-351, doi:10.1016/s0065-2881(08)60212-6 (1998).

30. Clark, M. R. \& Rowden, A. A. Effect of deepwater trawling on the macroinvertebrate assemblages of seamounts on the Chatham Rise, New Zealand. DeepSea Res. Part I Oceanogr. Res. Pap. 56, 1540-1554, doi:10.1016/j.dsr.2009.04.015 (2009).

31. Murillo, F. J., Muñoz, P. D., Altuna, A. \& Serrano, A. Distribution of deep-water corals of the Flemish Cap, Flemish Pass, and the Grand Banks of Newfoundland (Northwest Atlantic Ocean): interaction with fishing activities. ICES J. Mar. Sci. 68, 319-332, doi:10.1093/icesjms/fsq071 (2011).

32. Pitcher, C. R., Poiner, I. R., Hill, B. J. \& Burridge, C. Y. Implications of the effects of trawling on sessile megazoobenthos on a tropical shelf in northeastern Australia. ICES J. Mar. Sci. 57, 1359-1368, doi:10.1006/jmsc.2000.0911 (2000).

33. Pitcher, C. R., Burridge, C. Y., Wassenberg, T. J., Hill, B. J. \& Poiner, I. R. A large scale BACI experiment to test the effects of prawn trawling on seabed biota in a closed area of the Great Barrier Reef Marine Park, Australia. Fish Res. 99, 168-183, doi:10.1016/j.fishres.2009.05.017 (2009).

34. Bjordal, Å. \& Løkkeborg, S. Longlining. (Oxford Fishing New Books, 1996).

35. Connolly, P. L. \& Kelly, C. J. Catch and discards from experimental trawl and longline fishing in the deep water of the Rockall Trough. J. Fish Biol. 49, 132-144, doi:10.1111/j.1095-8649.1996.tb06071.x (1996).

36. Kelleher, K. Discards in the world's marine fisheries: an update. FAO Fisheries Technical Paper. $N^{\circ} 470,131$ pp. Rome, FAO (2005).

37. Pham, C. K. et al. Total marine fishery catch for the Azores (1950-2010). ICES J. Mar. Sci. 70, 564-577, doi:10.1093/icesjms/fst024 (2013).

38. Løkkeborg, S. Best practices to mitigate seabird bycatch in longline, trawl and gillnet fisheries-efficiency and practical applicability. Mar. Ecol. Prog. Ser. 435, 285-303, doi:10.3354/meps09227 (2011).

39. Clarke, M., Borges, L. \& Officer, R. Comparisons of trawl and longline catches of deepwater elasmobranchs west and north of Ireland. J. Northwest Atl. Fish. Soc. 35, 429-442, doi:10.2960/J.v35.m516 (2005)

40. Coelho, R. et al. Reduction of elasmobranch by-catch in the hake semipelagic near-bottom longline fishery in the Algarve (Southern Portugal). Fish. Sci. 69, 293-299, doi:10.1046/j.1444-2906.2003.00620.x (2003)

41. Wallace, B. P. et al. Impacts of fisheries bycatch on marine turtle populations worldwide: toward conservation and research priorities. Ecosphere 4, art40, doi:10.1890/es12-00388.1 (2013).

42. Coelho, R. \& Erzini, K. Effects of fishing methods on deep water shark species caught as by-catch off southern Portugal. Hydrobiologia 606, 187-193, doi:10.1007/s10750-008-9335-y (2008).

43. Huse, I., Lokkeborg, S. \& Soldal, A. V. Relative selectivity in trawl, longline and gillnet fisheries for cod and haddock. ICES J. Mar. Sci. 57, 1271-1282, doi:10.1006/jmsc.2000.0813 (2000).

44. Suuronen, P. et al. Low impact and fuel efficient fishing-Looking beyond the horizon. Fish Res. 119, 135-146, doi:10.1016/j.fishres.2011.12.009 (2012).

45. Carvalho, N., Edwards-Jones, G. \& Isidro, E. Defining scale in fisheries: Small versus large-scale fishing operations in the Azores. Fish Res. 109, 360-369, doi:10.1016/j.fishres.2011.03.006 (2011).

46. Sumaila, U. R. et al. Subsidies to high seas bottom trawl fleets and the sustainability of deep-sea demersal fish stocks. Mar. Pol. 34, 495-497, doi:10.1016/ j.marpol.2009.10.004 (2010).

47. Braga-Henriques, A. et al. Diversity, distribution and spatial structure of the cold water coral fauna of the Azores (NE Atlantic). Biogeosciences 10, 4009-4036, doi:10.5194/bg-10-4009-2013 (2013).

48. Menezes, G. M., Sigler, M. F., Silva, H. M. \& Pinho, M. R. Structure and zonation of demersal fish assemblages off the Azores Archipelago (mid-Atlantic). Mar. Ecol. Prog. Ser. 324, 241-260, doi:10.3354/meps324241 (2006).

49. Tempera, F. et al. Condor seamount (Azores, NE Atlantic): A morpho-tectonic interpretation. Deep-Sea Res. Part II-Top. Stud. Oceanogr. 98, Part A, 7-23, doi:10.1016/j.dsr2.2013.09.016 (2013).

50. Menezes, G. M., Diogo, H. \& Giacomello, E. Reconstruction of demersal fisheries history on the Condor seamount, Azores archipelago (Northeast Atlantic). DeepSea Res. Part II-Top. Stud. Oceanogr. 98, Part A, 190-203, doi:10.1016/ j.dsr2.2013.02.031 (2013). 
51. Welsford, D. \& Kilpatrick, R. Estimating the swept area of demersal longlines based on in-situ video footage. Document WG-FSA-08/58. CCAMLR, Hobart, Australia. (2008)

52. Melo, O. \& Menezes, G. M. Projecto de acompanhamento de experiencia de pesca dirigida ao peixe-relógio (Hoplostethus atlanticus)-FISHOR. Arquivos do DOP, Série Estudos. 4: 2002 (In Portuguese) (2002).

53. Moran, M. J. \& Stephenson, P. C. Effects of otter trawling on macrobenthos and management of demersal scalefish fisheries on the continental shelf of northwestern Australia. ICES J. Mar. Sci. 57, 510-516, doi:10.1006/jmsc.2000.0718 (2000).

54. Wassenberg, T. J., Dews, G. \& Cook, S. D. The impact of fish trawls on megabenthos (sponges) on the north-west shelf of Australia. Fish Res. 58, 141-151, doi:10.1016/s0165-7836(01)00382-4 (2002).

55. Bergman, M. J. N. \& van Santbrink, J. W. Mortality in megafaunal benthic populations caused by trawl fisheries on the Dutch continental shelf in the North Sea in 1994. ICES J. Mar. Sci. 57, 1321-1331, doi:10.1006/jmsc.2000.0917 (2000).

56. Burridge, C. Y., Pitcher, C. R., Wassenberg, T. J., Poiner, I. R. \& Hill, B. Measurement of the rate of depletion of benthic fauna by prawn (shrimp) otter trawls: an experiment in the Great Barrier Reef, Australia. Fish Res. 60, 237-253, doi:10.1016/s0165-7836(02)00179-0 (2003).

57. Sparks-McConkey, P. J. \& Watling, L. Effects on the ecological integrity of a softbottom habitat from a trawling disturbance. Hydrobiologia 456, 73-85, doi:10.1023/a:1013071629591 (2001).

58. Yesson, C. et al. Global habitat suitability of cold-water octocorals. J. Biogeogr. 39, 1278-1292, doi:10.1111/j.1365-2699.2011.02681.x (2012).

59. Davies, A. J. \& Guinotte, J. M. Global Habitat Suitability for Framework-Forming Cold-Water Corals. PLoS ONE 6, e18483, doi:10.1371/journal.pone.0018483 (2011).

60. Watson, R., Revenga, C. \& Kura, Y. Fishing gear associated with global marine catches II. Trends in trawling and dredging. Fish Res. 79, 103-111, doi:10.1016/ j.fishres.2006.01.013 (2006).

61. Watson, R., Kitchingman, A., Gelchu, A. \& Pauly, D. Mapping global fisheries: sharpening our focus. Fish. Fish. 5, 168-177, doi:10.1111/j.14672979.2004.00142.x (2004).

62. Watson, R., Revenga, C. \& Kura, Y. Fishing gear associated with global marine catches - I. Database development. Fish Res. 79, 97-102, doi:10.1016/ j.fishres.2006.01.010 (2006)

\section{Acknowledgments}

This research received funding from the European Community 7th Framework Programme under the CoralFISH (213144) and HERMIONE (226354) projects, the Fundação para a Ciência e a Tecnologia (FCT), Fundo Regional da Ciência, Tecnologia
(FRCT), through the research project 2020-M2.1.2/I/026/2011 (Pro-Convergência), the Project CONDOR (EEA grants - PT0040/2008) and the project "Annual demersal fish monitoring research cruises" funded by the Azores Government. The authors also acknowledge funds provided by FCT-IP/MEC to LARSyS Associated Laboratory and IMAR-University of the Azores (R\&DU \#531), Thematic Area E, through the Strategic Project (PEst-OE/EEI/LA0009/2011-2014, COMPETE, QREN) and by the Government of Azores FRCT multiannual funding. CKP was supported by an FCT doctoral grant (SFRH/ BD/66404/2009, COMPETE/QREN). TM, a Ciência Researcher, is co-funded by IMAR and FCT/Portuguese Ministry for Education and Science (POPH, COMPETE/QREN European Social Fund). A.B.H. was supported by a doctoral grant from the Azores Government (FRCT/M3.1.2/F/016/2008). We thank the scientists aboard the RV Arquipélago in particular Alexandra Rosa and Diana Catarino for the collection of bycatch organisms and Valentina Matos and Irís. Sampaio for identification of cold-water corals, José-Nuno Gomes-Pereira and Fernando Tempera for help with the video analyses, Reg Watson and the Pew Charitable Trust through the Sea Around Us project for providing the global bottom trawling data, Chris Yesson, Andrew Davies and John Guinotte for providing the global habitat suitability models for octocoral and scleractinian corals, F. Vandeperre for discussions on the methodological and statistical approach, and Eduardo Isidro and Ricardo S. Santos for helpful discussions. We also thank the fisheries observers, ROV and the research vessels crews. The Open Access of this paper was paid under the Strategic Project (PEst-OE/EEI/LA0009/2013-2013) (COMPETE, QREN).

\section{Author contributions}

C.K.P. and T.M. conceived the idea, performed analyses, and wrote the manuscript; H.D. collected and analyzed the fishing effort data; F.V. assisted with the statistical analysis; A.B.H. identified the corals and analyzed part of the video data; F.P. and G.M. contributed to the design of the project.

\section{Additional information}

Supplementary information accompanies this paper at http://www.nature.com/ scientificreports

Competing financial interests: The authors declare no competing financial interests. How to cite this article: Pham, C.K. et al. Deep-water longline fishing has reduced impact on Vulnerable Marine Ecosystems. Sci. Rep. 4, 4837; DOI:10.1038/srep04837 (2014).

This work is licensed under a Creative Commons Attribution-NonCommercialNoDerivs 3.0 Unported License. The images in this article are included in the article's Creative Commons license, unless indicated otherwise in the image credit; if the image is not included under the Creative Commons license, users will need to obtain permission from the license holder in order to reproduce the image. To view a copy of this license, visit http://creativecommons.org/licenses/by-nc-nd/3.0/ 